ZOOLOGIA 31 (2): 114-118, April, 2014

http://dx.doi.org/10.1590/S1984-46702014000200002

\title{
Natural history of Micrablepharus maximiliani (Squamata: Gymnophthalmidae) in a Cerrado region of northeastern Brazil
}

\author{
Francisco Dal Vechio ${ }^{1,3}$, Renato Recoder ${ }^{1}$, Hussam Zaher $^{2} \&$ Miguel Trefaut Rodrigues $^{1}$
}

\author{
${ }^{1}$ Departamento de Zoologia, Instituto de Biociências, Universidade de São Paulo. Rua do Matão, Travessa 14, 321 , Cidade \\ Universitária, 05508-090 São Paulo, Brazil. \\ ${ }^{2}$ Museu de Zoologia, Universidade de São Paulo. Avenida Nazaré 481, Ipiranga, 04263-000 São Paulo, Brazil. \\ ${ }_{3}^{3}$ Corresponding author. E-mail: francisco.dalvechio@gmail.com
}

\begin{abstract}
Micrablepharus maximiliani (Reinhardt \& Luetken, 1861) is a microteiid lizard widely distributed in the open areas of South America. Little is known about its ecology and reproductive biology. Here, we analyzed aspects of the natural history of a population of M. maximiliani from a Cerrado area in the state of Piauí, northeastern Brazil. Our results suggest that the reproductive activity of $M$. maximiliani might be seasonal in the Cerrado, since reproductive females were observed only in the dry season, whereas reproductive males were present in both seasons. Vitellogenic follicles and oviductal eggs were found simultaneously in one female, suggesting that females may produce more than one clutch per season. Sexual dimorphism was observed in body shape, and individuals were mainly restricted to a typical savanna physiognomy. The diet consisted of small arthropods, including spiders, crickets and cockroaches as the most important items.
\end{abstract}

KEY WORDS. Diet; ecology; lizards; reproduction; sexual dimorphism.

Micrablepharus maximiliani (Reinhardt \& Luetken, 1861) is a small gymnophthalmid lizard (about $4 \mathrm{~cm}$ of snout-vent length) that is widely distributed throughout open areas of tropical South America (Vanzolini 1988, Ávila-Pires 1995, Rodrigues 1996). In Brazil, it is found in open and semi open habitats, along the Cerrado domain, and in mesic Caatinga habitats (VAnzolini et al. 1980, Werneck \& Colli 2006, Moura et al. 2010). It is also present in the Atlantic Forest of eastern Brazil, associated with coastal restingas, open habitat enclaves, in transitional areas between the Caatinga and Cerrado domains, or in isolated forests known as "Brejos de Altitude" (Freire 1996, Silva et al. 2006, Moura et al. 2010, Abrantes et al. 2011).

This species is a semi-fossorial lizard, often associated with rock outcrops, leaf-litter and bare ground, usually found in sandy-soil habitats, or inside termite mounds (Rodrigues 1996, 2003, Mesquita et al. 2006, Werneck et al. 2009). Sexual dimorphism is present and only males have femoral pores (Rodrigues 1996). Although commonly sampled in herpetofaunal inventories, little is known about basic aspects of their natural history and there is practically no information available on its reproductive strategy.

Here, we provide for the first time a comprehensive study of the natural history of M. maximiliani, presenting information on the reproductive condition, diet, habitat use, and sexual dimorphism of a population from a locality in the northern Cerrado, state of Piauí, Brazil.

\section{MATERIAL AND METHODS}

Field work was carried out at Estação Ecológica UruçuíUna (EEUU) $\left(08^{\circ} 50^{\prime} \mathrm{S}, 44^{\circ} 10^{\prime} \mathrm{W}\right)$, located in the northern extremity of the Brazilian Cerrado, in the southwestern corner of the state of Piauí. The vegetation of the EEUU is classified as woody savanna (CASTRO 1985). The relief is characterized by dissected plateaus that range from 480 to $620 \mathrm{~m}$ a.s.l., separated by valleys. The climate is dry to sub-humid, with high mean annual temperatures around $25^{\circ} \mathrm{C}$, and the dry and wet seasons extending from March to November and from December to March, respectively (CASTRO 1985).

Samplings were conducted along three campaigns, two during the rainy season (February $10^{\text {th }}$ to March $9^{\text {th }} 2000$ and January $9^{\text {th }}$ to February $\left.1^{\text {st }} 2001\right)$ and one in the dry season (16$28^{\text {th }}$ July 2000). We sampled the main physiognomic subunits present in the region with the use of pitfall traps with drift fences, complemented by active search. Each sampling unit contained one central and three external $30 \mathrm{~L}$ buckets arranged in a Y-shape disposition and joined together by four meters long plastic fences.

Four main physiognomies were sampled: Cerrado sensu stricto - typical savanna vegetation found around the EEUU headquarters and at the top of Serra Grande plateau, characterized by dense tree and herbaceous layers, but without a closed canopy. The soil is sandy and covered by significant floral diversity; Gallery forest - evergreen forests composed by trees

2014 Sociedade Brasileira de Zoologia | www.sbzoologia.org.br | www.scielo.br/zool All content of the journal, except where identified, is licensed under a Creative Commons attribution-type BY-NC. 
up to $15 \mathrm{~m}$ high, forming a closed canopy. The soil is less sandy than in the surrounding savannas, and the ground is covered with a dense litter; Dry forest - a dense but thin arboreal vegetation with a discontinuous canopy, usually present around rocky outcrops surrounded by savannas; Hillside forest - a forest characterized by a closed canopy and sandy soil, with high deposition of organic matter forming a dense litter. Table I shows the total effort and capture rates in each physiognomy. A detailed methodology, map and habitat photographs can be found in DAL VECHIO et al. (2013).

A representative number of the captured specimens were euthanized with a lethal injection of anesthetics, fixed in 10\% formol, and preserved in $70 \%$ alcohol. Voucher specimens are housed at the herpetological collection of the Museu de Zoologia da Universidade de São Paulo (MZUSP), São Paulo, Brazil. The specimens examined were: MZUSP-90226, MZUSP90236, MZUSP-90237, MZUSP-90242, MZUSP-90243, MZUSP90246-51, MZUSP-90262, MZUSP-90265, MZUSP-90772-75, MZUSP-90777-81, MZUSP-90784, MZUSP-90873.Ten morphometric measurements were taken using a Mitutoyo digital caliper: snout-vent length (SVL), length between limbs (LBL), head height (HH), head width (HW), head length (HL), femur length (FL), tibia length (TL), foot length (FTL), humeral length (HUL), forearm length (FAL).

To assess the reproductive condition and diet, we dissected the preserved individuals. Their stomachs were removed and their contents were examined under stereomicroscope. Each prey item was identified to the more inclusive group up to the level of Order. We calculated the importance index (Ix), as modified from HOWARD (1999), which represents the relative importance of each category in relation to the entire diet. We also calculated niche breadth using the inverse of the diversity index of Simpson (SIMPSON 1949). Diet overlap between the sexes was calculated with the niche overlap index of PIANKa (1974). The diet overlap index varies from 0 (no overlap) to 1 (complete overlap).

The reproductive condition was determined by gonad inspection. Females were considered sexually mature when vitellogenic follicles or oviductal eggs were present. Males were considered sexually mature when convoluted epididymides and/or testes hypertrophy were present. We evaluated sexual dimorphism in morphometry through analysis of variance (ANOVA) performed using SPSS v.15.0 with a significance level of 0.05 .

\section{RESULTS}

A total of 67 individuals of Micrablepharus maximiliani (Fig. 1) were captured during all three campaigns at the EEUU, 53 individuals were captured in the cerrado sensu stricto (Fig. 2), seven in the dry forest, six in the gallery forest and only one in the hillside forest. The capture rate was similar for both seasons, but higher for the cerrado physiognomy (Table I).
Table I. Number of specimens of M. maximiliani captured in pitfall traps at Estação Ecológica Uruçuí Una in the wet and dry seasons. The sampling effort expended (in buckets $x$ days) and capture rate (individuals per bucket) in each season are presented.

\begin{tabular}{|c|c|c|c|c|c|c|c|}
\hline & \multicolumn{2}{|c|}{$\mathrm{N}$ captured } & \multicolumn{2}{|c|}{ Effort } & \multicolumn{3}{|c|}{ Capture rate } \\
\hline & Wet & Dry & Wet & Dry & Wet & Dry & Total \\
\hline Cerrado & 44 & 9 & 2840 & 800 & 0.0155 & 0.0113 & 0.0267 \\
\hline Dry forest & 4 & 3 & 1080 & 680 & 0.0037 & 0.0044 & 0.0081 \\
\hline Gallery forest & 2 & 4 & 1320 & 720 & 0.0015 & 0.0056 & 0.0071 \\
\hline Hillside forest & 1 & 0 & 1080 & 0 & 0.0009 & 0 & 0.0009 \\
\hline Total & 51 & 16 & 6320 & 2200 & 0.0081 & 0.0073 & 0.0079 \\
\hline
\end{tabular}

A sample of 24 adults was collected and preserved (12 males and 12 females): four females and six males captured in the dry season, eight females and six males captured in the rainy season. The sexes did not differ in body size (Anova; $\mathrm{F}_{1,23}=$ $3.487, \mathrm{p}=0.08$ ). Sexual dimorphism was observed in shape, with females presenting longer LBL (Anova; $\mathrm{F}_{1,23}=7.634, \mathrm{p}=$ 0.01 ), and males presenting longer FL (Anova; $\mathrm{F}_{1,23}=4.607, \mathrm{p}=$ 0.04 ) and HL (Anova; $\mathrm{F}_{1,23}=4.396, \mathrm{p}=0.04$ ) (Table II).

Table II. Morphometric variables with the corresponding mean \pm standard deviation and level of significance $p$ from analysis of variance (Anova) for sexual dimorphism. Values with significance $<0.05$ are presented in bold.

\begin{tabular}{lcccc}
\hline & $\begin{array}{c}\text { Males }(\mathrm{N}=12) \\
\text { Mean } \pm \text { SD }\end{array}$ & $\begin{array}{c}\text { Females }(\mathrm{N}=12) \\
\text { Mean } \pm \mathrm{SD}\end{array}$ & $\mathrm{F}$ & $\mathrm{p}$ \\
\hline $\mathrm{SVL}$ & $37.09 \pm 1.83$ & $38.35 \pm 1.44$ & 3.487 & 0.08 \\
$\mathrm{LBL}$ & $\mathbf{1 8 . 5 2} \pm \mathbf{1 . 2 9}$ & $\mathbf{1 9 . 8 5} \pm \mathbf{1 . 2 4}$ & $\mathbf{7 . 6 3 4}$ & $\mathbf{0 . 0 1}$ \\
$\mathrm{HH}$ & $4.03 \pm 0.33$ & $3.91 \pm 0.3$ & 0.843 & 0.37 \\
$\mathrm{HW}$ & $5.63 \pm 0.44$ & $5.37 \pm 0.31$ & 2.772 & 0.11 \\
$\mathrm{HL}$ & $\mathbf{7 . 8 4} \pm \mathbf{0 . 4 2}$ & $\mathbf{7 . 5 8} \pm \mathbf{0 . 1 1}$ & $\mathbf{4 . 3 9 6}$ & $\mathbf{0 . 0 4}$ \\
$\mathrm{FL}$ & $\mathbf{5 . 6 1} \pm \mathbf{0 . 3 8}$ & $\mathbf{5 . 3} \pm \mathbf{0 . 3 4}$ & $\mathbf{4 . 6 0 7}$ & $\mathbf{0 . 0 4}$ \\
$\mathrm{TL}$ & $4.7 \pm 0.25$ & $4.69 \pm 0.35$ & 0.004 & 0.95 \\
$\mathrm{FTL}$ & $6.93 \pm 0.55$ & $6.85 \pm 0.61$ & 0.113 & 0.74 \\
$\mathrm{HUL}$ & $3.66 \pm 0.43$ & $3.48 \pm 0.32$ & 0.205 & 0.25 \\
FAL & $6.92 \pm 0.59$ & $6.87 \pm 0.46$ & 0.038 & 0.85 \\
\hline
\end{tabular}

All four females captured during the dry season were reproductive, with three $(75 \%)$ presenting vitellogenic follicles and one (25\%) presenting vitellogenic follicles and two oviductal eggs simultaneously. All eight females captured during the wet season were not reproductive, and presented only translucent follicles. All dissected males presented convoluted epididymides and enlarged testes, and were thus considered reproductive regardless of the season.

Twenty four stomachs were analyzed and 36 items were identified in six prey categories. One item was not identified. 

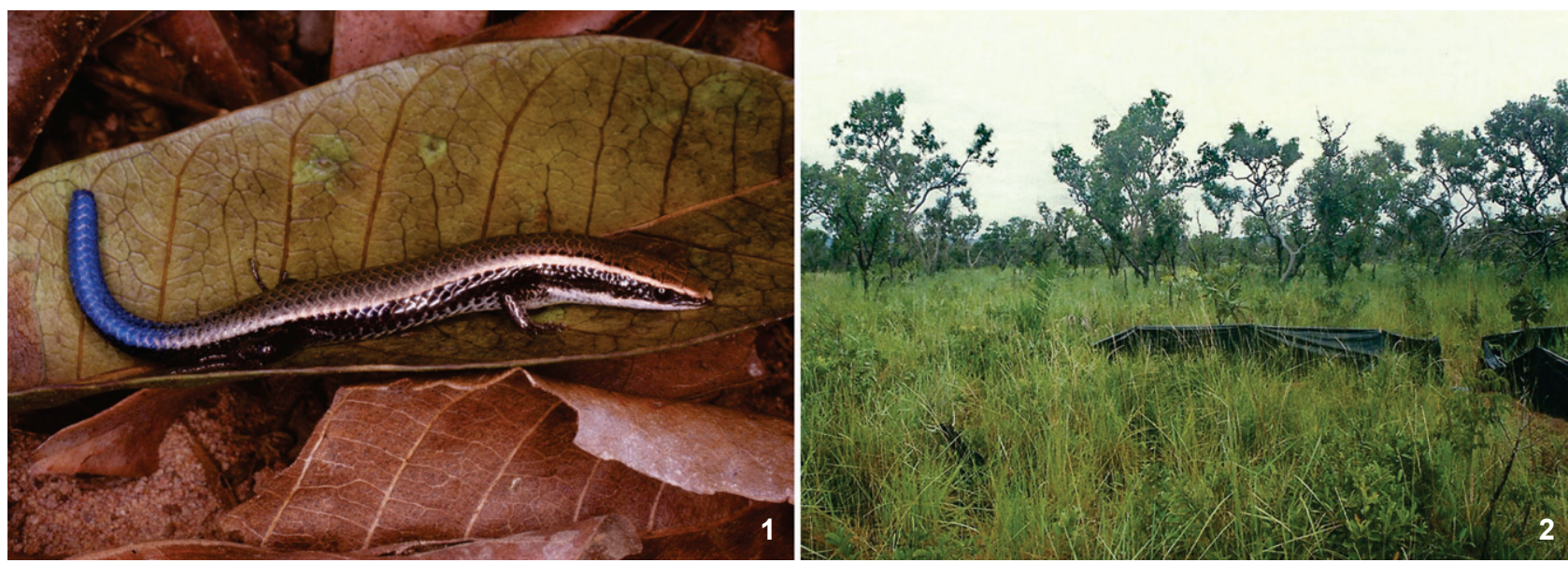

Figures 1-2. (1) Individual of Micrablepharus maximiliani with autotomized tail, captured in the Estação Ecológica Uruçuí Una; (2) a typical Cerrado habitat where the species was found.

Four stomachs were empty. Prey categories with higher importance index correspond to Araneae (0.48), Orthoptera (0.48) and Blattaria (0.34) (Table III). Niche breadth was 4.26, whereas dietary overlap between sexes was 0.92 .

Table III. Number $(\mathrm{N})$, percentage $(\% \mathrm{~N})$, frequency $(\mathrm{F})$, frequency in percentage (\% F) and importance index (Ix) of prey categories in the diet of Micrablepharus maximiliani from the Estação Ecológica Uruçuí Una.

\begin{tabular}{lrrrrc}
\hline & $\mathrm{N}$ & \multicolumn{1}{c}{$\% \mathrm{~N}$} & $\mathrm{~F}$ & $\% \mathrm{~F}$ & $\mathrm{Ix}$ \\
\hline Orthoptera & 11 & 29.73 & 9 & 37.50 & 0.48 \\
Blattaria & 8 & 21.62 & 6 & 25.00 & 0.34 \\
Coleoptera & 3 & 8.11 & 3 & 12.50 & 0.14 \\
Diptera & 2 & 5.41 & 2 & 8.33 & 0.10 \\
Aranae & 11 & 29.73 & 9 & 37.50 & 0.48 \\
Hymenoptera & 1 & 2.70 & 1 & 4.17 & 0.05 \\
Non-identified arthropod & 1 & 2.70 & 1 & 4.17 & 0.05 \\
\hline Total & 37 & & 24 & & \\
Niche breadth & 4.26 & & & & \\
\hline
\end{tabular}

\section{DISCUSSION}

Our results show that Micrablepharus maximiliani is more commonly found in the cerrado sensu stricto physiognomy in the EEUU. Preference for open habitats in this species is well established (Vanzolini 1988, Mesquita et al. 2006, Nogueira et al. 2009). In fact, even in the Atlantic Forest, M. maximiliani is usually found in association with open formations such as restingas (Freire 1996, Silva et al. 2006) or forest edges (Rodrigues 1996), being rarely found inside rainforests (Nogueira et al. 2009, Moura et al. 2010).
Sexual dimorphism has been previously reported for the species, with females lacking femoral pores (Rodrigues 1996). Our data suggest that females and males of M. maximiliani may also differ in the proportional lengths of trunk, hind limbs and head. The presence of longer trunks in females may be associated with a fertility advantage conferred by a larger space in the peritoneal cavity for egg development (OLsson et al. 2002, Cox et al. 2003). A larger trunk length in females is recurrent in many species of Gymnophthalmidae (VITT 1982, VITT \& ÁvilAPires 1998, BaLestrin et al. 2010). On the other hand, males presented larger femoral and head lengths than females, a pattern that seems to be common in species of lizards in which the exploration or defense of territories by males, favors success in finding mates (Perry et al. 2004, Peterson \& Husack 2006, Kaliontzopoulou et al. 2010). A similar pattern is also observed in other small-bodied microteiid lizards, in which males present larger hind limbs than females (VIтT 1982). Nevertheless, in the other species of the genus, Micrablepharus atticolus (RoDRIGUEs 1996), the sexes do not show dimorphism in morphometry (VIEIRA et al. 2000). Curiously, in this species both sexes present femoral pores (Rodrigues 1996).

The Cerrado has two well-defined weather seasons (a drywinter and a rainy-summer), which favor a seasonal reproductive cycle for most inhabitant lizard species (Colli 1991, VAN Sluys 1993, Wiederhecker et al. 2002, Colli et al. 2003, Mesquita $\&$ ColLi 2003). Our results suggest that the reproductive activity of females of M. maximiliani occurs in the dry season. Thus juveniles would be found from August to November, but sampling throughout the year would be necessary to confirm this pattern. Food supply may not be a limiting factor in the dry season, as it would be advantageous for the offspring spawning at a time with greater prey availability (TeLford 1971, MESQuita et al. 2006). Nevertheless, the presence of adequate microenvironments for the eggs to develop may also be con- 
strained during the rainy season (Telford 1971), as well as opportunities for females to thermoregulate, which may compromise the development of their eggs.

The presence of females bearing vitellogenic follicles and oviductal eggs simultaneously suggests that M. maximiliani can produce more than one clutch during the reproductive season. Vanzosaura rubricauda (Boulenger, 1902) a related species, also shows multiple clutches of two eggs, with a continuous reproduction cycle in the Caatinga (VITT 1982), but a seasonal one in the Chaco (Cruz 1994). A fixed clutch size of two eggs is a recurring pattern in many species of Gymnophthalmidae (Fitch 1970, Telford 1971, Sherbrooke 1975, Vitt 1982, ÁvilaPires 1995, Pianka \& Vitt 2003, Balestrin et al. 2010).

Our results suggest that specimens of $M$. maximiliani from the EEUU are opportunistic predators that feed on a variety of small arthropods, especially spiders, crickets and cockroaches. Although with a relatively small sample and without considering prey abundance in the habitat, our results are similar to those obtained from specimens of M. maximiliani from the Jalapão region, which mainly consumed crickets, spiders, and hemipterans (MEsquiTa et al. 2006), and from the Paranã River valley, which mainly consumed spiders, hemipterans and crickets (Werneck et al. 2009). The prey items consumed by $M$. atticolus were crickets, hemipterans, and spiders (VIEIRA et al. 2000). We observed a large dietary overlap between males and females in our sample, suggesting a lack of food partitioning between the sexes.

\section{ACKNOWLEDGEMENTS}

We are indebted to Deocleciano G. Ferreira, Head of the Ibama Regional Office, for his support. We are grateful to Mário de Vivo, Erika Hingst-Zaher, Renato Gregorin, Maria J. de J. Silva, Ana P. Carmignotto, Alexandre Percequillo, Renata C. Amaro, Luis F. Silveira, Andrés C. Mendez, Marcos A.N. de Sousa, Cristiano Nogueira, Dante Pavan, Marianna Dixo, Dalton M. Novaes, Giovanna G. Montingelli, Ricardo A. Fuentes, Rodrigo P. Ribeiro, Guilherme R. Britto, Felipe F. Curcio, and Paula H. Valdujo for their help in the field. We are also indebted to Carolina Mello for support with the collection at the MZUSP, Pedro Dias and Silvio Nihei (IB-USP) for identification of prey items, and Mauro Teixera Jr. for critically reading and commenting on a previous draft of this paper. This research was supported by grants from the Fundação de Amparo à Pesquisa do Estado de São Paulo (FAPESP), Conselho Nacional de Desenvolvimento Científico e Tecnológico (CNPQ), and Fundação Boticário para a Conservação da Natureza.

\section{LITERATURE CITED}

Abrantes, S.H.F.; M.M.R. Abrantes \& A.C.G.P. FalCÃo. 2011. A fauna de lagartos em três brejos de altitude de Pernambuco, nordeste do Brasil. Revista Nordestina de Zoologia 5: 23-29.
Ávila-Pires, T.C.S. 1995. Lizards of Brazilian Amazonia (Reptilia: Squamata). Zoologische Verhandelingen 299: 1-706.

Balestrin, R.L.; L.H. Cappellari \& A.B. OUteiral. 2010. Biologia reprodutiva de Cercosaura schreibersii (Squamata, Gymnophthalmidae) e Cnemidophorus lacertoides (Squamata, Teiidae) no escudo Sul-Riograndense, Brasil. Biota Neotropica 10: 131-139. doi: 10.1590/s1676-06032010000100013.

CAstro, A.A.F.J. 1985. Vegetação e Flora da Estação Ecológica de Uruçuí-Una (Resultados Preliminares), p. 251-261. In: Anais do XXXVI Congresso Nacional de Botânica. Curitiba, Sociedade Botânica do Brasil, Ibama, vol. 1.

Colli, G.R. 1991. Reproductive ecology of Ameiva ameiva in the Cerrado of central Brazil. Copeia 1991: 1002-1012. doi: $10.2307 / 1446095$.

Colli, G.R.; D.O. Mesquita; P.V.V. Rodrigues \& K. Kitayama. 2003. The ecology of the gecko Gymnodactylus geckoides amarali in a neotropical savanna. Journal of Herpetology 37: 694706. doi: 10.1670/180-02a.

Cox, R.M.; S.L. Skelly \& H.B. John-Alder. 2003. A Comparative test of adaptive hypotheses for size dimorphism in lizards. Evolution 57: 1653-1669. doi: 10.1554/02-227.

Cruz, F.B. 1994. Actividad reprodutiva en Vanzosaura rubricauda (Sauria: Teiidae) del chaco accidental en Argentina. Cuaderno de Herpetología 8: 112-1118.

Dal Vechio, F.; R.S. Recoder; Z. Hussam \& M.T. Rodrigues. 2013. The herpetofauna of the Estação Ecológica de Uruçuí-Una, state of Piauí, Brazil. Papéis Avulsos de Zoologia 53 (16): 225-243. doi: 10.1590/s0031-10492013001600001.

FттсH, H.S. 1970. Reproductive cycles of lizards and snakes. Lawrence, Museum of Natural History, University of Kansas, 247p.

Freire, E.M.X. 1996. Estudo ecológico e zoogeográfico sobre a fauna de lagartos (Sauria) das dunas de Natal, Rio Grande do Norte e da restinga de Ponta de Campina, Cabedelo, Paraíba, Brasil. Revista Brasileira de Zoologia 13 (4): 903-921. doi: 10.1590/S0101-81751996000400012.

Howard, A.K.; J.D. Forester; J.M. Ruder; J.S. Parmelee \& R. Powell. 1999. Natural History of a Terrestrial Hispaniolan Anole: Anolis barbouri. Journal of Herpetology 33: 702-706. doi: 10.2307/1565590.

Kaliontzopoulou, A.; M.A. Carretero \& G.A. Llorente. 2010. Sexual dimorphism in traits related to locomotion: ontogenetic patterns of variation in Podarcis wall lizards. Biological Journal of the Linnean Society 99: 530-543. doi: 10.1111/ j.1095-8312.2009.01385.X.

Mesquita, D.O. \& G.R. Colli. 2003. The ecology of Cnemidophorus ocellifer (Squamata, Teiidae) in a neotropical savanna. Journal of Herpetology 37: 498-509. doi: 10.1670/179-02a.

Mesquita, D.O.; G.R. Colli; F.G.R. França \& L.J. Vitt. 2006. Ecology of a Cerrado Lizard Assemblage in the Jalapão Region of Brazil. Copeia 2006: 460-471. doi: 10.1643

/0045-8511(2006)2006[460:eoacla]2.0.co;2.

Moura, M.R.; J.S. Dayrell \& V.A. São-Pedro. 2010. Reptilia, Gymnophtalmidae, Micrablepharus maximiliani (Reinhardt 
and Lutken, 1861): Distribution extension, new state record and geographic distribution map. Check List 6: 419-426.

Nogueira, C.; G.R. Colli \& M. Martins. 2009. Local richness and distribution of the lizard fauna in natural habitat mosaics of the Brazilian Cerrado. Austral Ecology 34: 83-96. doi: 10.1111/j.1442-9993.2008.01887.x.

Olsson, M.; R. Shine; E. Wapstra; B. Ujvari \& T. Madsen. 2002. Sexual dimorphism in lizard body shape: the roles of sexual selection and fecundity selection. Evolution 56: 15381542. doi: /10.1111/j.0014-3820.2002.tb01464.x.

Perry, G.; K. Levering; I. Girard \& T. Garland-JR. 2004. Locomotor performance and social dominance in male Anolis cristatellus. Animal Behaviour 67: 37-47. doi: 10.1016/j.anbehav.2003. 02.003 .

Peterson, C.G. \& J.F. Husack. 2006. Locomotor performance and sexual selection: individual variation in sprint speed of collared lizards (Crotaphytus collaris). Copeia 2006: 216-224. 10.1643/0045-8511(2006)6[216:lpassi]2.0.co;2.

PiAnKA, E.R. 1974. Niche overlap and diffuse competition. Proceedings of the National Academy of Sciences 71: 2141-2145. doi: 10.1073/pnas.71.5.2141.

Pianka, E.R. \& L.J. VitT. 2003. Lizards: Windows to the Evolution of Diversity. Berkeley, University of California Press, 333p.

Rodrigues, M.T. 1996. A New Species of Lizard, Genus Micrablepharus (Squamata: Gymnophthalmidae), from Brazil. Herpetologica 52: 535-541.

Rodrigues, M.T 2003. Ecologia e Conservação da Caatinga, p. 181-236. In: R. Leal; J.M.C. da Silva \& M. Tabarelli (Eds). Herpetofauna da Caatinga. Recife, Editora UFPE, 804p.

Sherbrooke, W.C. 1975. Reproductive cycle of a tropical teiid lizard, Neusticurus ecpleopus Cope, in Peru. Biotropropica 7: 194-207. doi: 10.2307/2989623.

Silva, S.T.; U.G. Silva; G.A.B. Sena \& F.A.C. Nascimento. 2006. A biodiversidade da Mata Atlântica alagoana: anfíbios e répteis, p. 65-76. In: F.B.P. Moura (Ed.). A Mata Atlântica em Alagoas. Maceió, Editora UFAL.

Submitted: 26.II.2013; Accepted: 20.IX.2013.

Editorial responsibility: Ana Lúcia Prudente
Simpson, E.H. 1949. Measurement of diversity. Nature 163: 688. doi: 10.1038/163688a0.

TELFORD-JR, S.R. 1971. Reproductive patterns and relative abundance of two microteiid lizard species in Panama. Copeia 1971: 670-675. doi: 10.2307/1442635.

VAN SLuYS, M. 1993. The reproductive cycle of Tropidurus itambere (Sauria, Tropiduridae) in southeastern Brazil. Journal of Herpetology 27: 28-32. doi: 10.2307/1564901.

VANZOLINI, P.E. 1988. Proceedings of a workshop on Neotropical distributional patterns, p. 317-342. In: P.E. VANZOLINI \& W.R. Heyer (Eds). Distributional patterns of South American lizards. Rio de Janeiro, Academia Brasileira de Ciências.

Vanzolini, P.E; A.M.M. Ramos-Costa \& L.J. Vitt. 1980. Répteis das Caatingas. Rio de Janeiro, Academia Brasileira de Ciências, $161 \mathrm{p}$.

Vieira, G.H.C.; D.O. Mesquita; A.K. Péres-Jr; K. Kitayama \& G.R. Colli. 2000. Natural history: Micrablepharus atticolus. Herpetological Review 31: 241-242.

ViTT, L.J. 1982. Sexual dimorphism and reproduction in the microteiid lizard, Gymnophthalmus multiscutatus. Journal of Herpetology 16: 325-329. doi: 10.2307/1563730.

VitT, L.J. \& T.C.S. Ávila-Pires. 1998. Ecology of Two Sympatric Species of Neusticurus (Sauria: Gymnophthalmidae) in the Western Amazon of Brazil. Copeia 1998: 570-582. doi: 10.2307/1447787.

Werneck, F.P. \& G.R. Colli. 2006. The lizard assemblage from Seasonally Dry Tropical Forest enclaves in the Cerrado biome, Brazil, and its association with the Pleistocenic Arc. Journal of Biogeography 33: 1983-1992. doi: 10.1111/j.13652699.2006.01553.x.

Werneck, F.P.; G.R. Colli \& L.J. VitT. 2009. Determinants of assemblage structure in Neotropical dry forest lizards. Austral Ecolology 34: 97-115. doi: 10.1111/j.1442-9993.2008.01915.x.

WiederheCKER, H.C.; A.C.S. Pinto \& G.R. Colli. 2002. Reproductive ecology of Tropidurus torquatus (Squamata: Tropiduridae) in the highly seasonal Cerrado biome of central Brazil. Journal of Herpetology 36: 82-91. doi: 10.2307/1565806. 